\title{
Psychoanalysis Ego Image by Freudian: Study of Psychology in the Main Character of the Tale of Hang Tuah
}

\author{
Tia Pratiwi $^{1}$, Sarwiji Suwandi², Nugraheni Eko Wardhani ${ }^{3}$, \\ ${ }^{123}$ Sebelas Maret University, Indonesia \\ pratiwitia95@student.uns.ac.id
}

\begin{abstract}
The tale of Hang Tuah is one type of old literature. This folklore tells the story of the main character named Hang Tuah who became the commander of a kingdom in a Malay land called the kingdom of Malacca. The purpose of this study is to analyze the psychology of the main character of the tale of Hang Tuah based on Sigmund Freud's psychoanalytic theory. This study uses descriptive qualitative study by analyzing the contents contained in the tale of Hang Tuah by Bot GenootSchap. The data in this study are in the form of behavior carried out by the main character, and the psychology of the main character based on the actions taken. Data sources in this study are in the form of a book entitled the tale of Hang Tuah, supporting primary books, and relevant journals and research as well. The data analysis technique used in this study is content analysis. The results of this study can be concluded that Based on the analysis carried out on the tale of Hang Tuah story script, it can be concluded that the character, Hang Tuah, has a personality that is consistent with what is conveyed in Sigmund Freud's psychoanalytic theory, especially in the ego aspect.
\end{abstract}

Keywords: the psychology of the main character; psychoanalysis by Sigmund Freud; aspect id; the tale of Hang Tuah.

\section{Introduction}

The tale (Hikayat) is one type of old literature originating from Malay land. The term regarding of this folklore was first used by writers in Malay land to describe stories related to history or past stories (Braginsky, 1998).

Literature and psychology are two different fields of science, psychology discusses human behavior related to the environment (Daulay, 2014). Whereas literature according to Wellek, n.d.is a creative human activity that produces a written and printed work of art.

Various existing literary works certainly have stories played by the characters. The characters in the story have an inherent personality. This is actually what becomes a bridge between psychology and literature as Endaswara explained (2008). It was also conveyed by Saraswati who analyzed the personality in novels entitled Ayat-Ayat Cinta and Laskar Pelangi which were analyzed using psychoanalytic theory by Sigmund Freud (Saraswati, 2011)

The psychology of the main character explained by Sigmund Freud is one theory that is very often used in studies that discuss psychoanalysis which is often called the theory of Freudianpsychoanalysis(Cloud, 2017; Schetz\&Szubka, 2012). As contained in the explanation delivered by Arminjon, Ansermet, and Magistretti (2010) so as byToksöz (2018) which states that Freudian psychoanalysis is divided into three aspects, namely id, ego, and superego.

The psychological side of the main character in a literary work explained by Minderop considers that psychoanalysis is used to analyze a person's mental state both related to patients with neurological disorders and social irregularities. This is also supported by Minderop (2011) which states that the character's psychology depiction carried out by the author is described through literary works. The depiction of the character's psychology is divided into three aspects, namely id, ego, and superego (Alwisol, 2014).

In line with other literary works, the tale of Hang Tuah also has the main character. The folklore which describes a commander from Malay land also has a personality character that is 
inherent in the main character. This is what later became the link between psychoanalysis and literature.

The tale of Hang Tuah tells of a commander in a kingdom called Bintan. The kingdom was very famous at that time since it had a double wise commander. The attitudepossessed by Hang Tuah is the same as that of humans in general, Hang Tuah also has a turmoil that exists in him (Efendi\&Muttaqien, 2018).

\section{Methodology}

This is a descriptive-qualitative study. A descriptive qualitative study is a type of study used to describe various phenomena encountered in the analysis process based on documents that have been found. This is in line with what was conveyed by Endaswara (2008) andLexy J. Moleong (2019) which says that descriptive-qualitative is a study that is used to observe and understand a process of phenomena that occur which are then explained using words.

The data that is the focus of the analysis in this study is the psychological depiction of the characters analyzed based on the conversations made by the main character, the behavior carried out by the main character and the description of the behavior of the main character in the view of other characters. The data collection carried out in this study was carried out as follows: 1) analyzing the behavior carried out by the main character based on the conversation carried out by the main character of the tale of Hang Tuah; 2) analyzing the psychology of the main character based on the actions taken by the main character of the tale of Hang Tuah; 3) concludes the psychology of the main character of the tale of Hang Tuah in accordance with the psychoanalysis of the character according to Sigmund Freud. The data sources contained in this study are based on 1) The book entitled Hikayat Hang Tuah by Bot GenootSchap (Schap, 2010); 2) primary books in accordance with this study, and 3) journals related to this study. The data analysis technique used in this study describes three mental aspects of the character according to Sigmund Freud.

\section{Result and Discussion}

Based on the three aspects of personality conveyed by Sigmund Freud namely the id, ego, and superego, an analysis of one of the three aspects is carried out, which is ego, a component of personality based on reality. The explanation of the analysis of the ego aspects is described as follows:

"Maka Hang Tuah seraya tersenyum, Hai saudaraku, pada bicara hamba baik juga kita berperang di atas pulau ini, karena perahu kita kecil, tewas juga kita; ia tiga buah serta dengan besarnya dan senjatanya pun lengkapp, lagi orangnya pun banyak sukar juga kita melawan dia." (page 24)

"Hang Tuah then spoke with a smile. We also fought on this island, but because our ship is small, then most likely we will lose. In addition, weapons and the number of troops from the opposing parties are also more numerous and more sophisticated, so it is very difficult to defeat. " (page 24)

Based on the above quotation, it can be seen that the personality traits of the ego according to the Freudian theory are illustrated through Hang Tuah's words which invite other 
friends to save themselves by fighting against the enemy. Actually doing war is not a good thing but if the fact is urgent so that the war can be carried out.

“...Maka Hang Tuah kelima bersaudarairu pun sudah memegang senjata, tiga-tiga bilah seligi dan seorang. Apabila hamper musuh itu kedepan hadapan Hang Tuah ,maka di tetak Hang Tuah kena pahanya, lalu terduduk tiada dapat bangkit lagi." (page 24)

"... Hang Tuah also holds a weapon, three spear blades. When the enemy almost approached, Hang Tuah used the spear he carried to repel the enemy." (page 24)

Based on the above quotation, it can be seen that the personality traits of the ego according to the Freudian theory are illustrated by the war carried out by Hang Tuah and his friends in an effort to save themselves.

“...Maka Hang Tuah pun menghunus kerisnya, lalu menyerbukan dirinya pada musuh yang dua puluh itu, serta ditikamnya oleh Hang Tuah, dua orang mati. “ (page 25)

"With his weapon namely keris, Hang Tuah also advanced against the twenty-numbered enemy, then stabbed his keris until two enemies died." (page 25)

Based on the above quotation, it can be seen that the personality traits of the ego according to the Freudian theory are illustrated by the actions of Hang Tuah. Even though killing is a bad thing, if you are in a very urgent situation you can do it as an effort to save yourself.

"Maka Hang Tuah pun tersenyum seraya berkata, sungguh saudara, tetapi bukannya orang mengamuk padan mengembari dengan keris, patutlah dengan kapak atau dengan kayu." (page 33)

"Smiling Hang Tuah then said, Would it be better to fight someone or advance against the enemy to use weapons such as keris, axes or wood". (page 33)

Based on the above quotation, it can be seen that the personality traits of the ego according to the Freudian theory are illustrated through Hang Tuah's words that address a person's emotions with a very good logic of thinking.

"Maka sembah Tun Tuah, "Daulat tuanku, terlalu baik seperti sembah patik bendahara itu, bukan barang-barang hukum akan segala raja-raja yang dimakzul kandari pada takhta kerajaan itu." (page 77)

"Then said TunTuah, "It is too good for the treasurer, not the legal things of the kings that are proclaimed from the throne of the kingdom." (page 77)

Based on the above quotation, it can be seen that the personality traits of the ego according to the Freudian theory are illustrated by the attitude of Hang Tuah which views a thing not based on its desire, but in accordance with the reality that occurs.

"Maka saudagar itu pun memandang kepada bantara Tun Tuah. Maka di dalam hatinya, apa juga asalnya bentaratun Tuahini, tiada patut dijadikan bentar, hulu balang juga lainnya. Pada penglihatan bentara kiri ini bergelar laksamana juga pada akhirnya, karena orang bijaksana". (page 84)

"So according to a merchant, because of his character who is known to be wise, Hang Tuah has been forced to be appointed as an admiral or royal commander." (page 84)

Based on the above quotation, it can be seen that the personality traits of the ego according to the Freudian theory are illustrated by the views of others who see Hang Tuah as someone who has a wise personality so Hang Tuah deserves to be made a royal commander.

"Maka kata bentara TunTuah, jika demikian baiklah, esok hari patik persembahkan kebawah duli paduka kakanda, tetapi kepada bicara patik, lulus juga sembah patik, karena pekerjaan kebajikan juga." (page 88) 
"As Hang Tuah said," Tomorrow I will leave and this is solely for good." (page 88)

Based on the above quotation, it can be seen that the personality traits of the ego according to the Freudian theory are illustrated by the attitude of hangs in making decisions not solely because of their wants and interests but based on the situation and reality.

"Maka sembah TunTuah, Daulat tuanku, patik mohonkan ampun dan kurnia, patik lihat terlalu sangatlah hal yang dirasainya. Jika tiada pergi mengail, tiada boleh makan. Itulah pada bicara patik, baik juga duli yang dipertuan lepaskan kebenua Keling itu dari pada ditahan serupa itu, karena orang kaya saudagar itu, hendak membawa paduka adinda ini kebenua Keling." (page 88)

Wouldn't it be better if your majesty let go of the Raja Muda and take him to Rivet so that his life would improve." (page 88)

Based on the above quotation, it can be seen that the personality traits of the ego according to the Freudian theory are illustrated by Hang Tuah's statement to the king who should release Raja Muda who is being punished for being taken to the continent of Keling since ecause even in the land of Bintan, he is difficult in his life.

"Maka sembah bentaratun Tuah, " Pada bicara patikakan pekerjaan duli yang dipertuan melepaskan paduka adinda kebenua Kelingini, bukan barang-barang pekerjaan juga. Paduka adinda selaku ini tiada akan baik jadi di dengar oleh ayahanda di bukit seguntang itu. Syahdan apatah nama patik yang tua di Melaka ini." (page 89)

"Is it not better to release Raja Muda and be taken to the Rivet before the father of your royal king knows?" (page 89)

Based on the above quotation, it can be seen that the personality traits of the ego according to Freudian theory are illustrated by Hang Tuah's statement to the King who suggested that the king release his younger brother, Raja Muda, to be taken to the Rivet before the royal king's father knew what the king had done to his younger brother.

“... Maka kata tun Tuah apatah salahnya sebenarnyalah, karena datuk orang besartak dapat tiada akan kedengaran jugalah ke Bukit Seguntang, maka akan nama datuk jugadisebut orang." (page 92)

"If the person is truly guilty, then he deserves punishment and vice versa." (page 92)

Based on the above quotation, it can be seen that the personality traits of the ego according to the Freudian theory are illustrated by Hang Tuah's attitude which gives advice not solely based on his desire but based on the reality.

\section{Conclusion}

The tale of Hang Tuah is old literature that tells the story of a commander from the kingdom of Malacca named Hang Tuah. Hang Tuah has a pretty good personality. This can be seen from the depiction of Hang Tuah's character based on the conversation that was made and the statements of other figures who supported the situation. Based on the analysis carried out on the tale of Hang Tuah story script, it can be concluded that the character, Hang Tuah, has a personality that is consistent with what is conveyed in Sigmund Freud's psychoanalytic theory, especially in the ego aspect. This personality is reflected in Hang Tuah's behavior which always takes decisions not based on desires or norms but did he make a decision based on the situation and reality. 


\section{Acknowledgments}

I gratefully thank the parties who have helped and participated in providing support to complete this article, especially to both parents, supervisors, and editors of journals who are willing to publish this article. Hopefully, this article can contribute, be useful as well as possible for the world of education.

\section{References}

Alwisol. (2014). Psikologi Kepribadian (edisi revisi). Malang: UMM Press.

Arminjon, M., Ansermet, F., \& Magistretti, P. (2010). The homeostatic psyche: Freudian theory and somatic markers. Journal of Physiology Paris, 104(5-6), 272-278. https://doi.org/10.1016/j.jphysparis.2010.08.006

Awan, M. A. (2017). Freudian Notion of Psychoanalysis: Its Implications in Contemporary Teaching Practices. Advances in Language and Literary Studies, 8(5), 150-154. Retrieved from

http://ezproxy.lib.uconn.edu/login?url=https://search.ebscohost.com/login.aspx?direct=tr $\mathrm{ue} \& \mathrm{db}=$ eric $\& \mathrm{AN}=\mathrm{EJ} 1160124 \&$ site $=$ ehost-live

Braginsky. (1998). Yang indah, berfaedah dan kamal: Sejarah sastra Melayu abad 7-19. Jakarta: Kencana.

Daulay, N. (2014). Pengantar Psikologi dan Pandangan Al-Qur`an tentang Psikologi. Jakarta: Kencana.

Efendi, A. N., \& Muttaqien, M. Z. (2018). Educational Values in "Hikayat Hang Tuah" Malay Folktale. LEKSEMA: Jurnal Bahasa Dan Sastra, 2(2), 131. https://doi.org/10.22515/ljbs.v2i2.646

Endaswara, S. (2008). Metodologi Penelitian Sastra. In MedPres.

Lexy J. Moleong, D. M. A. (2019). Metodologi Penelitian Kualitatif (Edisi Revisi). PT. Remaja Rosda Karya. https://doi.org/10.1016/j.carbpol.2013.02.055

Minderop, A. (2011). Psikologi Sastra, Karya Sastra, Metode, Teori, Contoh Kasus. Jakarta: Pustaka Obor.

Saraswati, E. (2011). "Pribadi dalam Novel Ayat-Ayat Cinta dan Laskar Pelangi: Telaah Psikoanalisis Sigmund Freud." Jurnal Artikulasi, 12(2), 883--901. Retrieved from http://download.portalgaruda.org/article.php?article=97448\&val=260\&title=PRIBADI

DALAM NOVEL AYAT-AYAT CINTA DAN LASKAR PELANGI: TELAAH PSIKOANALISIS SIGMUND FREUD

Schap, B. G. (2010). Hikayat Hang Tuah I. Jakarta: Pusat Bahasa Pendidikan Nasional.

Schetz, A., \& Szubka, T. (2012). Freudianism. Encyclopedia of Applied Ethics, 345-352. https://doi.org/10.1016/B978-0-12-373932-2.00203-9

Toksöz, İ. (2018). Psychoanalytic Analysis of the Characters in Beckett?s "Waiting for Godot." International Journal of Science and Research (IJSR), 6(12), 66-68. https://doi.org/10.21275/art20178416

Wellek, R. W. W. (n.d.). Teori Kesusastraan. Jakarta: Gramedia Pustaka Utama. 